\title{
More Intra-Region Direct Investment through Economic Integration? Modelling the Experience of the EU's Single Market
}

\author{
Stefanie A. Haller \\ Eonomic and Social Research Institute
}

\begin{abstract}
I apply the fixed versus variable cost trade-off associated with a multinational firm's choice between investing abroad and exporting to a setting where the multinational is located inside an economically integrating region. I find that reducing obstacles to investment unambiguously favours setting up plants. When trade barriers decrease, typically, there will be consolidation of investment or a switch to exports. If, however, distance to destination markets matters for the multinational, export platform investment in one country will be induced. This highlights that export platform investment may be a supply option even inside an integrating region once countries are not assumed to be homogenous. Overall, the predictions of the model are indicative of some of the developments in trade and direct investment among EU countries during the Single Market Programme.
\end{abstract}

-JEL Classification: F23, F15, F21

- Key Words: Multinational Firm, Foreign Direct Investment, Trade, Regional Economic Integration

\section{Introduction}

Countries that joined regional trading and integrating agreements reaped the largest benefits from the growth in trade and investment in the generally favourable environment of multilateral trade liberalisation after World War II. For example in

\footnotetext{
*Corresponding address: Stefanie A. Haller; Economic and Social Research Institute, Whitaker Square, Sir John Rogerson's Quay, Dublin 2, Ireland, email: stefanie.haller@esri.ie.

( $2010-$ Center for International Economics, Sejong Institution, Sejong University, All Rights Reserved.
} 
Europe, positive effects from integration on trade and on foreign direct investment (FDI) were already observable during the formative years of the European Community (Balassa, 1975, Yannopoulos, 1990). More strikingly, along with the implementation of the Single Market Programme the share of intra-region direct investment in total direct investment of the European Union (EU) doubled (see Figure 1). ${ }^{1}$ The aim of the Single Market Programme (SMP) was to take European integration beyond the early elimination of internal tariffs and to achieve broadscale harmonisation in a number of areas by 1992. Regarding trade and direct investment, the remaining impediments were customs and tax controls at borders, technical barriers, and restrictive practices in government procurement, but also a variety of technical and product standards or complicated bureaucratic procedures for establishing new plants (Monti, 1996).

The model presented in this paper rationalises how these policy measures may have affected multi-national firms in their choice of serving other countries inside an integrating region via exports or the establishment of a local subsidiary in a way that is consistent with the near-doubling of intra-region direct investment and the increase in trade observed during the SMP. I use a specification similar to that in Neary (2002) who examines supply strategies of a multinational located outside an integrating region. I adapt this model to a setting where both the multinational and its target markets are located inside an integrating region. The model uses the traditional trade-off between the variable cost of exporting and the fixed costs of setting up a plant. ${ }^{2}$ The first departure from Neary's (2002) model is that countries differ in market size in a way that has implications for both trade and investment. The second departure is that in the present model the variable cost of exporting has two components - atrariff and a distance cost. The tariff is the same throughout the integrating region and may be affected by policy whereas the distance cost is fixed. The setting is such that the multinational is located in a country in the integrating region from where it has to overcome a greater distance to the markets it wants to serve than the firms based in these markets have to bridge to serve each other. Thus, the model captures the idea that even in a region where economic integration has been underway for some time differences between countries remain and there will be groups of countries that are closer to each other than to the rest of the union countries.

\footnotetext{
${ }^{1}$ Similar increases of intra-region FDI can be observed for NAFTA (see e.g. various articles in Rugman, 1994) and ASEAN (Bende-Nabende, 2000).

${ }^{2}$ See Markusen (2002) for a textbook treatment.
} 
This paper follows the literature on foreign direct investment that allows for strategic interaction between firms. Previous work has directed attention mainly at the impact of economic integration on the changes in supply strategies of firms located outside the integrating region. Norman and Motta (1993) show that both market growth and improved accessibility due to economic integration will induce external firms to switch from exporting to FDI. Motta and Norman (1996) consider the impact of integration on the supply decision of an external firm and of two firms located inside an integrating region. For the external firm the above result continues to apply, while for the intra-region firms they obtain consolidation of intra-region investment to exporting. Neary (2002) compares the supply strategies of an MNE located outside an integrating region. He obtains tariff-jumping FDI to all union countries when the external tariff is high and the fixed cost of a new plant is relatively low. As internal tariff barriers go down, the MNE is likely to switch to export platform investment. With competition from domestic firms, one possible outcome is that the profits from investing or exporting are diluted to such an extent that the foreign firm decides not to supply the region at all ('fortress Europe outcome'). It may, however, also happen that the foreign firm is able to prevent intra-region firms from supplying another country by setting up a plant there.

The model predicts that reducing obstacles to investment inside an integrating region unambigu-ously favours setting up plants. When it comes to lowering trade barriers, the MNE's supply decision depends on its location relative to the market(s) it wants to serve in the integrating region. If the $\mathrm{MNE}$ is in a rather remote location, lower trade barriers will induce it to set up a plant in the largest destina-tion country and export to the adjacent markets from there. Both of these findings capture some of the greenfield investment associated with the Single Market Programme. In addition, the MNE's decision to invest in the largest destination country is in line with about half of intra-EU direct investment going to Germany, France and the UK. The result related to lowering barriers to investment is an obvious one, but typically the fixed cost of setting up a plant is not regarded as a variable that can be influenced by policy. The result related to lowering trade barriers when the MNE is located further away from its target market(s) inside the integrating region is typically the one obtained for firms located out-side the integrating region. Thus, by allowing for differences between countries inside an integrating region, export platform investment becomes a possible supply mode for firms that are located inside this region. If, in turn, the MNE is located close to its destination market(s) in the integrating region, - similar to Motta and Norman (1996) - lowering trade barriers 
will induce consolidation of investment or exports. This is indicative of the increase in cross-border mergers and acquisitions together with the SMP and the increase in exports. These predictions are derived in a setting where the MNE can act as a monopolist in its destination markets, which may serve as an approximation when the MNE has a strong technological or organisational advantage.

When the MNE faces competition from a local incumbent and from exporters from the adjacent destination market(s), trade barriers need to be lower for the MNE to serve these markets at all. If it is profitable to do so, however, it will be mainly in the form of investment. In fact, for low but not too low trade barriers, investment by the MNE will deter the incumbents in the adjacent countries from exporting. Hence, this case is again indicative for greenfield investment or consolidation of investment for very low levels of trade cost. Thus, while a number of the results in the model have been obtained in previous work relating to FDI from outside the integrating region, this paper is the first to apply them to a setting where all firms are located inside an integrating region. The set of predictions it generates is consistent with a number of the observed developments in trade and investment among EU countries during the Single Market Programme.

The remainder of the paper is structured as follows: Section II describes the developments in trade and foreign direct investment in the EU during the Single Market Programme. In Section III the model setup is presented. The MNE's supply decision is analysed when it is able to act as a monopolist in Section IV, and when it faces competition from a local incumbent in its destination markets in Section V. Section VI summarises and concludes.

\section{Trade and Foreign Direct Investment during the EU's Single Market Programme}

Figure 1 shows the evolution of trade and direct investment in the EU around the time of the introduction of the SMP. Intra-EU12 trade as a share of total EU12 trade increased by 5 percentage points between 1986 and 1992 to a level of roughly $55 \%$, whereas intra-EU direct investment inflows and outflows doubled their share in total EU12 FDI flows from about $20 \%$ in the mid-1980s to more than $40 \%$ in 1993. Similar developments are visible for EU15. Intra-EU trade accounts for approximately $60 \%$ of total EU trade and intra-EU direct investment flows remained at a level of about $50 \%$ in total EU15 FDI after 1993. In every year between 1982 and 1994 the three largest markets - Germany, France and the UK - 
Figure 1. Evolution of trade flows in EU12 (1980-1994) and EU15 (1980-2000)
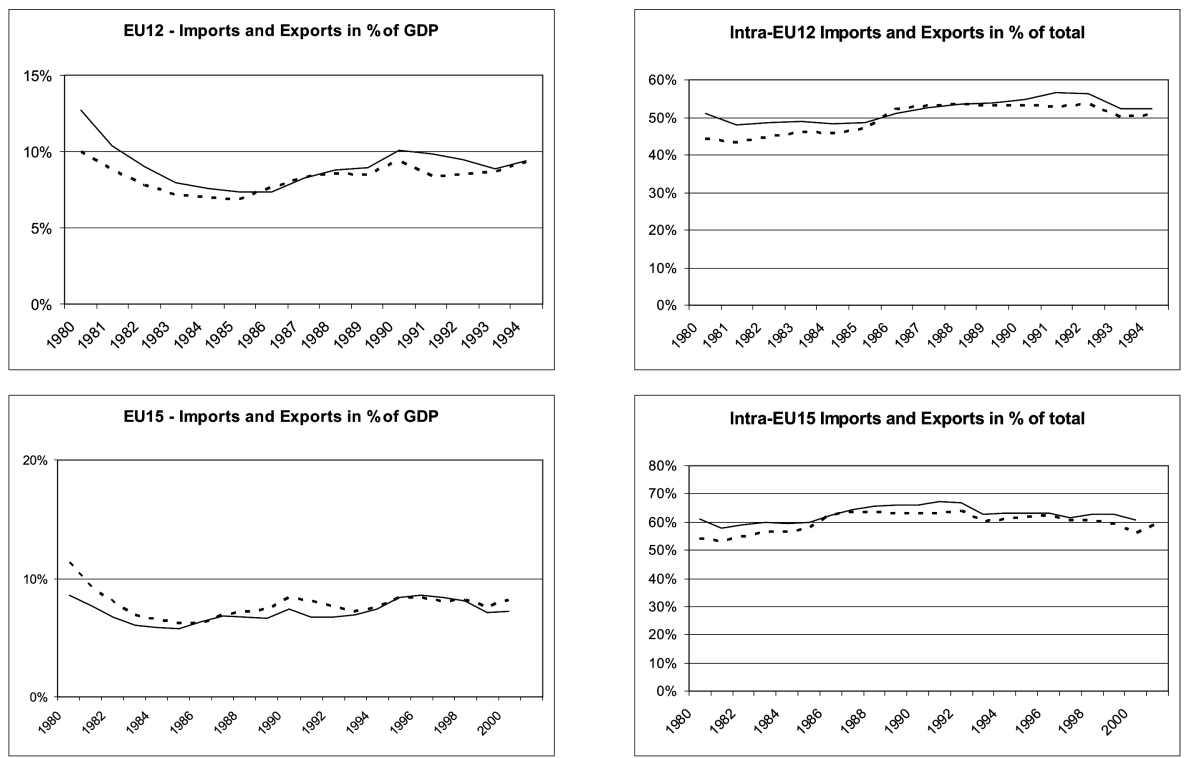

- Exports

-.- Imports

Evolution of direct investment flows in EU12 (1982-1994) and EU15 (1980-2000)
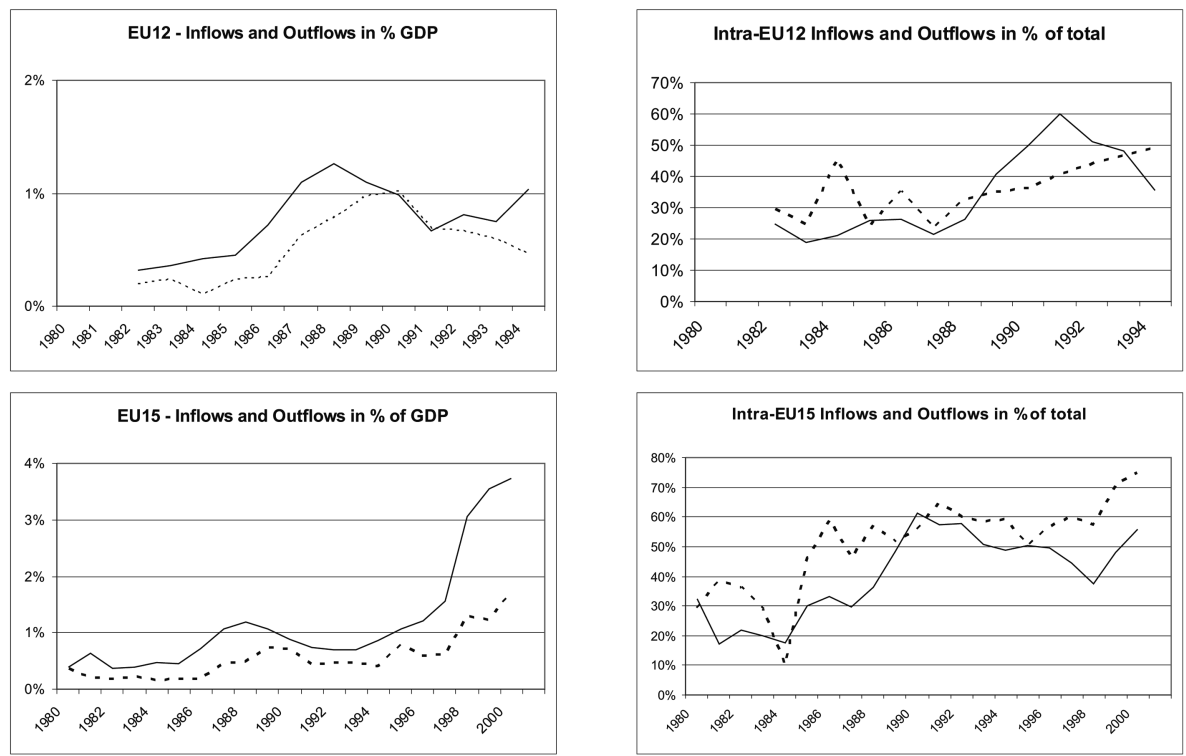

$\begin{array}{ll}\text { _. Outflows } \\ \ldots & \text { Inflows }\end{array}$

Sources: Author's compilation from OECD data. 
received between $47 \%$ and $62 \%$ of intra-EU12 direct investment inflows.

The increase in FDI flows to the EU during the implementation of the SMP was accompanied by an increase in direct investment stocks, in particular those of EU and Japanese firms (Dunning, 1997a, EC, 1998a). A large share of FDI results from mergers and acquisitions (M\&A). According to Sleuwaegen (1998), they account for between $46 \%$ and $63 \%$ in the period from 1986 to 1994 in total EU12 inward FDI. Looking at M\&As within the EU only, the number of mergers between firms located in the same member state doubled between 1987 and 1989 and diminished continuously thereafter. Cross-border mergers within the EU quadrupled after 1988 but fell back substantially after 1990, however the number of deals in 1994 (913) was still close to three times the level in 1987 (Sleuwaegen, 1998, European Economy, 1999).

Dunning (1997b) summarises the existing econometric work on direct investment associated with the Single Market in the EU. Among the few studies concerned with its impact on intra-EU direct investment, van Aarle (1996) finds that the EU12 countries trade and invest relatively more with and in each other, and, moreover, that the SMP has had a positive effect on inward and outward FDI and trade within the EU. Pain (1997) and Pain and Lansbury (1997) look at the stock of direct investment in the UK and Germany, respectively. They conclude that the SMP had a significant positive impact on the aggregate level of intra-EU direct investment by British as well as by German corporations in both industrial and services sectors.

\section{The Model}

Following the literature on foreign direct investment, I model the multinational's supply decision as a trade-off between the variable cost of exporting (such as trade and distance cost) and the fixed cost of setting up a new plant. My analysis also accounts for empirical results from gravity equations, where market size and distance capture much of the variation (see e.g. Clegg (1998) for the EU).

As outlined above, the object of analysis is a multinational firm located in a country which is a member of an economically integrating region (union). The countries in this region are supposed to have reduced internal trade barriers, but 
there are still obstacles to trade and also to investment. ${ }^{3}$ These obstacles translate into costs for firms when trading with or investing in the union member countries. In other words, in the region under consideration, economic integration is under way, but far from complete. Markets are therefore regarded as segmented. ${ }^{4}$

The model largely follows the setup in Neary (2002). However, a number of changes are intro-duced in order to take the model from a situation where investment from outside the integrating region is the main focus to the setting here that is concerned with FDI inside an integrating region. In the following, I will specify where the model differs from Neary (2002). I look at firms in a single industry that are producing a homogeneous good, i.e. the model is one of partial equilibrium. In particular, consider a potential multinational enterprise located in a peripheral country when deciding to supply some or all of $n(n \geq 2)$ core countries that differ in market size $s_{i}$, but are symmetric with respect to the other parameters. This implies that both exporting and setting up a plant are a function of market size; this is more comprehensive than Neary's (2002) extension where the costs of setting up a plant differ between countries. The indirect demand function $p\left(x, s_{i}\right)$ is such that $\frac{\partial p}{\partial s_{i}}>0$ and $\frac{\partial^{2} p}{\partial s_{i}^{2}} \leq 0$. Assume that countries are ordered according to market size: $1 \geq s_{1} \geq \cdots \geq s_{n}>0$. The MNE produces at constant marginal cost $c$, that is, for simplicity, set equal to zero. If it decides to engage in foreign activity, this does not affect output and profits in its home country.

The main concern of the model is to see how changes in a multinational's cost of trading and investing affect its mode of supply. Trade and investment are associated with different costs: Setting up a plant in another country entails a fixed setup $\cos t$, which depends on barriers to investment.

Exporting, in turn, is subject to a per-unit trade cost $\tau(0 \leq \tau \leq 1)$. This trade cost is composed of two parts, a tariff $t$ and a distance $\operatorname{cost} d: \tau^{d}=t+\mathrm{d}$. The underlying

${ }^{3}$ For the EU, the extent of such barriers before the SMP can be gauged from the Eurostat Business Survey (EC 1998c), which questioned some 13,500 enterprises during the first half of 1995. Regarding trade barriers, the effect of the SMP on the elimination of customs documentation, on the deregulation of freight transport, and on the elimination of delays at frontiers was reported positive by, respectively, $60 \%, 43 \%$, and $56 \%$ of the enterprises. Concerning potential barriers to investment, $31 \%$ of the firms questioned felt a positive impact from the harmonisation of technical regulations and/or standards, $32 \%$ from the mutual recognition of technical regulations and/or standards, $23 \%$ from the conformity of assessment procedures, and $13 \%$ from simplified patenting procedures.

${ }^{4}$ Venables (1990) compares the implications of a reduction in trade costs in a model of international trade under oligopoly when markets are segmented (i.e. when prices are set separately for each market) and when markets are integrated (i.e. when one price applies to all markets). 
notion is that trade cost can be split up in a part that is given by a country's location $(d)$ and a part that can be influenced by policy $(t)$. The tariff $t(0 \leq t \leq 1)$ is meant to be representative of any (non-)tariff trade barriers. It is assumed to be the same for all trade within the union. The distance cost $d(0 \leq d \leq 1)$ depends on the location of the country from where the exports take place: $d \in\{\mathrm{z}, \mathrm{y}\}$ takes the value $y$ if the MNE exports from its home country in the periphery to the core, it takes the value $z$ if exports take place within the core. The idea is that even in a region where economic integration has been underway for some time there will be groups of countries that are closer to each other than to the rest of the union countries, thus $0 \leq z<y$. One way of interpreting the distance cost is to view it as a transport cost: consider, for example, the way commodities have to travel from the Nordic countries to the central or Southern members of the EU. An alternative way of looking at it is in terms of cultural proximity, for example the costs of doing business may differ between groups of countries due to a common language or in terms of culture or the way of doing business. ${ }^{5}$ While the trade cost composites of the tariff and the distance cost $t+y(t+z)$ from the periphery (core) look very similar to the trade $\operatorname{cost} \mathrm{t}(\tau)$ from outside (within) the integrating region in Neary (2002), the fact that they are split into a (variable) tariff and a (fixed) distance cost component yields somewhat different results when examining a reduction in trade barriers.

Thus, when serving the core the MNE's alternatives are associated with different costs. First, if it exports from its home country in the periphery it faces a per unit trade cost $\tau^{y}=t+y$. Second, it can set up a plant in one of the core countries and serve the other core countries with exports from there. Establishing a plant in a core country, on the one hand, saves the MNE the tariff and the distance costs to this country, but, on the other hand, involves the fixed cost $f$ of setting up a plant. As the core countries are closer to each other, exporting within the core comes at the lower per unit cost of $\tau^{z}=t+z$. Third, the MNE can decide to establish plants in more than one of the core countries, in which case FDI buys it preferential access to all of these markets at the cost of setting up. Not to engage in any core country at all remains, of course, also an option for the MNE. Figure 2 illustrates the trade cost between the MNE's home country $\mathrm{P}$ and two core countries $\mathrm{C}_{1}$ and

\footnotetext{
${ }^{5}$ The evidence on border effects and home bias suggests that regions that are close to each other do not extend beyond national borders. Nitsch (2002) finds that even after the SMP, EU countries trade on average ten times more within national borders than with other EU countries; Head and Mayer (2000) obtain a similar result at the industry level.
} 
Figure 2. Trade and distance cost within the integrating region

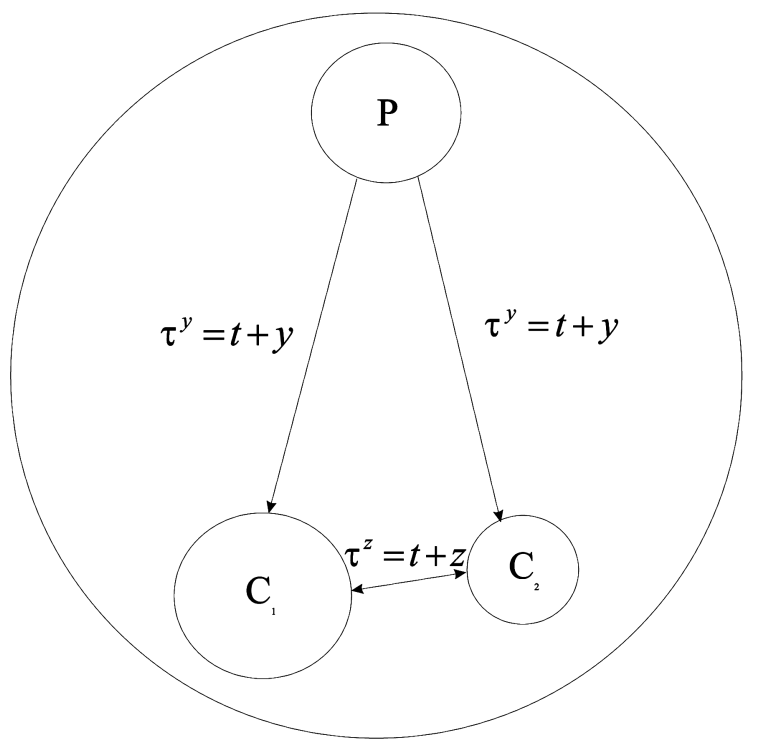

$\mathrm{C}_{2}$, where $\mathrm{C}_{1}$ is larger than $\mathrm{C}_{2}$.

In the following section, I first analyse the MNE's supply decision treating it as a monopolist. I then analyse the situation where the MNE faces competition from one incumbent firm in each core country. In this setting, the MNE's supply decision can have a strategic component. The analysis is set out in a general form. To illustrate ideas each section is accompanied by an example with linear demands of the form $p\left(x, s_{i}\right)=\left(1-\frac{x}{s_{i}}\right)$ with $0 \leq x \leq s_{i} \leq 1$ for well-defined prices. ${ }^{6}$

\section{The Supply Decision of the MNE as a Monopolist}

First, the decision of a potential multinational located in a peripheral country is modelled under the assumption that it is the only supplier in this industry. The multinational can, thus, act as a monopolist under any supply regime. There are no other firms that might enter the market. This setting may be a good approximation for a firm with a technological or organisational advantage, making it more likely

\footnotetext{
${ }^{6}$ Defining the indirect demand function in a more general way as $p(x)=a-b x\left(a>0, b>0, \frac{a}{b} \leq x \leq a\right)$ and assuming that the marginal cost of production $c$ is non-zero, gives $\frac{a-c}{b}$ as an alternative measure
for market size (see Rowthorn (1992) for a more detailed discussion).
} 
to start production abroad. This applies in particular, whenever this firm manages to advance into a market where competitors have yet to establish themselves.

The MNE's profits from exporting to a core country $i$ are given by $\pi_{i}\left(s_{i}, \tau^{d}\right)=\pi_{i}$ $\left(s_{i}, t+d\right) .{ }^{7}$ They are increasing in the size of the market $s_{i}$ and decreasing in trade $\operatorname{cost} \tau^{d}$. If the tariff and the distance cost are at a sufficiently high level, it will not be profitable to export to any of the $n$ core countries. In general, the prohibitive level of $t$ given $s_{i}$ and $d$ is defined implicitly by $\pi\left(\tilde{t}, \bar{s}_{i}, \bar{d}\right)=0$. The prohibitive tariff $\tilde{t}$ is smaller, the smaller the market size of country $i$ and the larger the distance $\operatorname{cost} d$. If the MNE decides to serve all $n$ core countries via exports from its home country in the periphery $\left(X_{P}\right)$ at distance cost $y$, its profits are given by

$$
\Pi^{X_{P}}=\sum_{i=1}^{n} \pi_{i}\left(s_{i}, \tau^{y}\right)=\sum_{i=1}^{n} \pi_{i}\left(s_{i}, t+y\right)
$$

Alternatively, the multinational can set up a plant in one of the core countries and supply the remaining core countries with exports. If it sets up a plant in a core country the MNE becomes a monopolist in that country, facing the fixed cost of setting up a plant $f$, but no other supply $\operatorname{cost}\left(\pi_{i}\left(s_{i}, 0\right) \equiv \pi_{i}\left(s_{i}\right)\right)$. Exporting to the other core countries $\left(X_{C}\right)$ entails the tariff and the within-core distance cost $z$. Other things being equal, as profits are increasing in market size, the MNE will invest first in the core country with the largest market (I, 1), earning

$$
\Pi^{I, 1+X_{C}}=\pi_{1}\left(s_{1}\right)-f+\sum_{i=2}^{n} \pi_{i}\left(s_{i}, \tau^{z}\right)=\pi_{i}\left(s_{1}\right)-f+\sum_{i=2}^{n} \pi_{i}\left(s_{i}, t+z\right)
$$

Comparing exports from the MNE's home country to investing in one country and exporting from there, investing in core country 1 is profitable if

\footnotetext{
${ }^{7}$ For the given specification of variable cost, profits can be shown to be convex in the trade barrier and distance cost, irrespective of the functional form of the demand function. The result of maximising operating profits $\left(\max _{x} \pi(\cdot)=\max _{x}\left[p\left(x, s_{i}\right)-\mathrm{c}-\tau\right] x\right)$ by the choice of sales in country $i$ can be written as $\pi^{*}=\pi\left(p\left(x^{*}, s_{i}\right), x^{*}, \tau\right)$. By the envelope theorem $\partial \pi^{*} / \partial \tau=\partial \pi / \partial \tau=-x^{*}$, and, thus $\partial^{2} \pi^{*} / \partial \tau^{2}=-d x^{*} / d \tau$
}

From the first-order condition one can see that $x^{*}$ is decreasing in $\tau$, and hence $\pi^{*}$ is convex in $\tau$. 


$$
\begin{gathered}
\Pi^{I, 1+X_{C}}-\Pi^{X_{P}} \\
=\underbrace{\pi_{1}\left(s_{1}\right)-f-\pi_{1}\left(s_{1}, t+y\right)}_{\begin{array}{c}
\gamma_{y}\left(s_{1}, t+y, f\right) \\
+++-
\end{array}}+\underbrace{\sum_{i=2}^{n}\left(\pi_{i}\left(s_{i}, t+z\right)-\pi_{i}\left(s_{i}, t+y\right)\right)} \\
\quad \begin{array}{c}
\chi\left(s_{i}, t+z, t+y,(n-1)\right) \\
+-++
\end{array}+
\end{gathered}
$$

is positive. The first term, $\gamma_{y}\left(s_{1}, t+y, f\right)$, measures the difference in profits between investing in country $1\left(\pi_{1}\left(s_{1}\right)-f\right)$, and exporting to this country from where the MNE is located $\left(\pi_{1}\left(s_{1}, t+y\right)\right)$, i.e. it is the net gain from avoiding the tariff and the distance cost by investing. If this expression is positive, it is always profitable to establish a plant abroad. As can be seen from the profit function, $\gamma_{y}\left(s_{1}, t+y, f\right)$ is increasing in the trade cost from the periphery $t+y$, and decreasing in fixed cost $f$. By the definition of the indirect demand function, it is increasing in market size $s_{i}$.

The second term $\chi\left(s_{i}, t+z, t+y,(n-1)\right)$ sums the differences in profits between exporting within the core and exporting from the periphery over all countries that the MNE can access at the lower distance cost by investing in country 1 . In other words, country 1 can be viewed as an 'export platform' to the other core countries. This export platform gain is always positive, since $y>z$ and profits $\pi_{\mathrm{i}}\left(s_{i}, t+z\right)$ and $\pi_{\mathrm{i}}\left(s_{i}, t+y\right)$ are decreasing in trade cost. That is, this term can render investing in one core country profitable even if the trade cost avoiding gain (the first term in equation (3)) is negative. $\chi\left(s_{i}, t+z, t+y,(n-1)\right)$ is decreasing in the within-core trade cost $t+z$ but increasing in the core-periphery trade cost $t+y$. By the convexity of profits in $\tau^{\mathrm{d}}$, the export platform gain is decreasing in t, i.e. $\pi_{i}\left(s_{i}\right.$, $t+z)$ decreases by more than $\pi_{i}\left(s_{i}, t+y\right)$ when $t$ increases. Moreover, $\chi\left(s_{i}, t+z\right.$, $t+y,(n-1))$ is increasing in the number of countries $(n-1)$ close to country 1 and in their market size $s_{i}$. This means that investing in country 1 is more attractive the more countries can be served at a low distance and the larger their size.

Setting up plants in $m(m \leq n)$ core countries instead earns the MNE profits of

$$
\begin{aligned}
\Pi^{I, m+X_{C}}=\sum_{i=1}^{m}\left[\pi_{i}\left(s_{i}\right)-f\right]+\sum_{i=m+1}^{n} \pi_{i}\left(s_{i}, t+z\right) \\
=\Pi^{I, m-1+X_{C}}+\gamma_{z}\left(s_{m}, t+z, f\right) \\
++-
\end{aligned}
$$


where $\gamma_{z}\left(s_{m}, t+z, f\right)=\pi_{m}\left(s_{m}\right)-f-\pi_{m}\left(s_{m}, t+z\right)$. The profits from investing in $\mathrm{m}$ countries can be expressed as a function of the profits from investing in $m-1$ countries plus the term $\gamma_{z}(\mathrm{sm}, t+z, f)$. It is profitable to invest in an additional core country as long as this trade cost avoiding gain is positive. $\gamma_{z}(s m, t+z, f)$ depends on trade and fixed cost as well as on market size in the same way as $\gamma_{z}\left(s_{m}, t+y, f\right)$. However, here instead of $y$ the lower within-core distance cost $z$ enters, implying that the additional gain from investing in a further core country will always be lower than the profit from the investment in country 1 . In addition, $\gamma_{z}\left(s_{m}, t+z\right.$, $f$ )depends on the market size of country $m$ and not on that of the larger country 1 . Thus, the lower within-core distance cost and the smaller market size can make it less profitable to invest in many or all core countries. If setting up in all countries is profitable $\left(\gamma_{z}\left(s_{m}, t+z, f\right)>0\right.$ for $\left.m=1, \cdots, n\right)$, total profits amount to

$$
\Pi^{I, n}=\sum_{i=1}^{n}\left[\pi_{i}\left(s_{i}\right)-f\right]
$$

implying that fixed cost cannot exceed $f=\pi_{i}\left(s_{i}\right)$ in each country $i$, respectively; i.e. the upper bound for investment $\overline{f_{s_{i}}}$ increases with the size of the market.

To summarise the impact of the different parameters, the incentive to invest in core country 1 stems from the difference in distance cost. In the absence of distance costs the MNE's decision would be driven only by the tariff and by market size. ${ }^{8}$ The decision between exporting and investing in the core in this case would simply be a trade-off between the tariff and the fixed cost. Without distance costs, equation (3) does not produce the export platform term, but only the term that arises from trade cost jumping

$$
\begin{aligned}
& \gamma\left(s_{1}, t, f\right)=\pi_{1}\left(s_{1}\right)-f-\pi_{1}\left(s_{1}, t\right) \\
& \quad++-
\end{aligned}
$$

This extends to investing in $m \leq n$ countries in the same way as in equation (4), and therefore, as long as $\chi\left(s_{m}, t, f\right)$ is positive it pays to invest in more than one core country in order to avoid the tariff. If, in addition, all core countries had the same

\footnotetext{
${ }^{8}$ Note that such a situation can be interpreted in two ways here: either all countries inside the union can be served at the same cost, or alternatively that the MNE is located amidst its destination markets in the core.
} 
market size, without distance cost the MNE would either invest in all core countries or export to all of them or not serve them at all depending on the levels of the tariff and the fixed cost.

In the presence of different within-core and periphery-core distance costs, however, a high trade cost from the periphery favours investment in more than one country via its positive impact on the trade cost avoiding gain. The first plant in the largest core country always gives the highest trade cost avoiding gain, because this saves the tariff and the periphery-core distance cost. Investing in any further core country will still save the MNE the tariff; it will, however, no longer save it the periphery-core distance cost but only the lower within-core distance cost. In addition, the smaller market size of these core countries makes investment there relatively less attractive.

Thus, regarding the SMP's attack on border formalities as a reduction in variable trade cost, a lower trade barrier $t$ implies that the gain from avoiding the trade cost will be smaller, but the export platform gain will be larger. The relative levels of $t+z$ and $t+y$ determine which of the two effects dominates. That is, if the trade cost from the periphery is high relative to the trade cost within the core, lowering the tariff will increase the profitability of export platform investment relative to exporting. This is also a possible outcome if periphery-core and withincore distance cost differ less, but there are many core countries that can be served from the export platform. Finally, if the trade cost from the periphery is close to the trade cost within the core, lowering $t$ will render trade cost jumping less attractive and, thus, exporting from the periphery will be preferred to export platform investment.

Going back to the empirical evidence, SMP measures aimed at barriers to trade have certainly eroded the trade cost avoiding motive further and, hence, facilitated exports. In turn, the outcome of the model where a lower tariff makes export platform investment more attractive is indicative of the surge in mergers and acquisitions across community borders. Empirically, very few studies find trade and direct investment to be substitutes for each other. For the EU, Fontagné and Pajot (2001) provide evidence more in favour of a complementary relationship. However, noting that intra-EU one-way trade decreased considerably during the implementation of the SMP, while at the same time intra-industry trade in differentiated products (trade in intermediate goods), which is generally associated 
with multinational activity, increased ${ }^{9}$, suggests that there has nonetheless been trade-replacing FDI. The lowering of non-tariff trade barriers is likely to be among the drivers of this development.

Concerning the cost of setting up, a high fixed cost makes exporting - even from the periphery - more attractive. However, also for intermediate values of fixed cost, setting up an export platform in one core country can be profitable. Due to SMP measures such as harmonisation of technical and product standards or improved business relations across countries one can argue that the fixed cost of setting up a plant has decreased. Therefore, investment in general has become more attractive. In particular, investing in a core country will be more attractive the more countries are accessible from this export platform. This captures mainly 'greenfield investment'. Moreover, it aligns with the fact that between 1986 and 1994 mergers and acquisition activity was highest in the distribution and wholesale sectors (Sleuwaegen, 1998). The example below illustrates both channels.

\section{Example with Linear Demands and Quantities as the Strategic Variable}

Taking the indirect demand function to be $p\left(s_{i}, x\right)=\left(1-\frac{x}{s}\right)$, output is given in the upper half of Table 1. Plugging these values into equation (3) the threshold between exporting from the periphery with investing in country 1and exporting from there can be obtained as

$$
f^{X_{P} \Leftrightarrow I, 1+X_{C}}=s_{1}\left(\frac{1}{2}\right)^{2}-s_{1}\left(\frac{1-t-y}{2}\right)^{2}+\sum_{i=2}^{n} s_{i}\left[\left(\frac{1-t-z}{2}\right)^{2}-\left(\frac{1-t-y}{2}\right)^{2}\right] .
$$

Comparing investment in $\mathrm{m}$ with investment in $m-1$ core countries, the equivalent to equation (4) is

$$
f^{I, m \Leftrightarrow I, m-1}=s_{m}\left(\frac{1}{2}\right)^{2}-s_{m}\left(\frac{1-t-z}{2}\right)^{2} .
$$

In Figure 3 equations (6) and (7) are plotted for two core countries with market size $s_{1}=1$ and $s_{2}=0.8$ in $f, t-$ space for given values of $z$ and $y(z=0.1, y=0.2$ (top) and $y=0,7$ (bottom)).

Looking at the impact of fixed cost, first fix $t$ at a low level (below the

\footnotetext{
${ }^{9}$ Two-way trade in vertically differentiated products increased from roughly $35 \%$ to $42 \%$ form 1986 to 1994, whereas the share of one-way trade in intra-EU12 trade decreased from about $47 \%$ to $38 \%$ over the same period (EC, 1998b, Ch. 4).
} 
Table 1. Sales of different firms under alternative supply strategies

The MNE as a monopolist

\begin{tabular}{cccc}
\hline \multirow{2}{*}{$\begin{array}{c}\text { supply } \\
\text { strategy }\end{array}$} & \multicolumn{4}{c}{ sales in country $i$ by the } \\
\hline$X_{P}$ & $s_{i} \frac{1-t-y}{2}$ & Home Firm $i: x_{i, i}$ & Core Firm $j: x_{j, i}$ \\
\hline$I, i+X_{C, j}$ & $s_{i} \frac{1}{2}$ & - & - \\
& & - & - \\
$I, n$ & $s_{i} \frac{1}{2}$ & - & - \\
\hline & & & Core Firm $j: x_{j, j}$ \\
\hline$X_{P}$ & $s_{j} \frac{1-t-y}{2}$ & Sales in country $j(j \neq i)$ by the & - \\
$I, i+X_{C}, j$ & $s_{j} \frac{1-t-z}{2}$ & - & - \\
$I, n$ & $s_{j} \frac{1}{2}$ & - & - \\
\hline
\end{tabular}

The MNE facing competition form $n$ core firms

\begin{tabular}{cccc}
\hline supply & \multicolumn{3}{c}{ supply sales in country $i$ by the } \\
\cline { 2 - 4 } strategy & MNE $0: x_{0, \mathrm{i}}$ & Home Firm $i: x_{i, i}$ & Core Firm $j: x_{j, i}$ \\
\hline$X_{P}$ & $s_{i} \frac{1-2 t-(n+1) y+(n-1) z}{n+2}$ & $s_{i} \frac{1+n t+y+(n-1) z}{n+2}$ & $s_{i} \frac{1-2 t+y-3 z}{n+2}$ \\
$I, i+X_{C, j}$ & $s_{i} \frac{1+(n-1) t+(n-1) z}{n+2}$ & $s_{i} \frac{1+(n-1) t+(n-1) z}{n+2}$ & $s_{i} \frac{1-3 t-3 z}{n+2}$ \\
$I, n$ & $s_{i} \frac{1+(n-1) t+(n-1) z}{n+2}$ & $s_{i} \frac{1+(n-1) t+(n-1) z}{n+2}$ & $s_{i} \frac{1-3 t-3_{z}}{n+2}$ \\
\hline \multirow{2}{*}{$X_{P}$} & $s_{j} \frac{1-2 t-(n+1) y+(n-1) z}{n+2}$ & $s_{j} \frac{1-2 t+y-3 z}{n+2}$ & $s_{j} \frac{1+n t+y+(n-1) z}{n+2}$ \\
$I, i+X_{C, j}$ & $s_{j} \frac{1-2 t-2 z}{n+2}$ & $s_{j} \frac{1-2 t-2 z}{n+2}$ & $s_{j} \frac{1+n t+n z}{n+2}$ \\
$I, n$ & $s_{j} \frac{1+(n-1) t+(n-1) z}{n+2}$ & $s_{j} \frac{1-3 t-3 z}{n+2}$ & $s_{j} \frac{1+(n-1) t+(n-1) z}{n+2}$
\end{tabular}

where $1 \leq i \leq m$ and $m<j \leq n$.

$X_{P}$ : Exports from the periphery $\mathrm{P}$

$I, i+X_{C,} j$ : Investment in country $i$ and exports within the core $C$ to country $j$

$I, n:$ Investment in $n$ (all) core countries 
prohibitive tariff for exports from the periphery $\left.\tilde{t}_{M N E_{P}}\right)$. For high fixed cost, the MNE will be exporting from the periphery $\left(X_{P}\right)$. When fixed costs decrease, export platform investment in one core country $\left(I, 1+X_{C}\right)$ becomes profitable and for low levels of fixed cost establishing a plant in both core countries $(I, 2)$ will be worthwhile. Next fix $t$ at a level above $\tilde{t}_{M N E_{P}}$. In this case the MNE will not find it profitable to supply the core (Ø) for high values of fixed cost. As fixed costs decrease, again, export platform investment in the largest core country becomes profitable $\left(I, 1+X_{C}\right)$. Even if $t$ is above the prohibitive level for exports within the core $\tilde{t}_{M N E_{C}}$, there will still be investment in core country $1(I, 1)$. Finally, for low levels of fixed cost the MNE will invest in both core countries $(I, 2)$.

As for the tariff, given a high level of fixed cost, the MNE will not supply the core $(\varnothing)$ if the tariff is prohibitive, otherwise it will export from the periphery $\left(X_{P}\right)$. For low levels of fixed cost, lowering tariff barriers unambiguously induces consolidation of investment $\left(I, 2\right.$ to $\left.I, 1+X_{C}\right)$. For intermediate values of fixed cost the effect of lowering $t$ depends on the level of periphery-core to within-core distance cost. If the periphery-core distance cost is not much higher than the within-core distance cost, a lower tariff barrier induces a shift from export platform investment in one core country $\left(I, 1+X_{C}\right)$ to exports from the periphery $\left(X_{P}\right)$, as in the upper panel of Figure 3. If, instead, the periphery-core distance cost is high relative to the within-core distance cost the opposite is the case: a lower tariff can induce a shift from exporting from the periphery $\left(X_{P}\right)$ to export platform investment in core country $1\left(I, 1+X_{C}\right)$ as in the lower panel of Figure 3 . This can be seen when deriving equation (6) with respect to t:

$$
\frac{\partial f^{X_{P}\left(I, 1+X_{C}\right)}}{\partial t}=\frac{1}{2}\left(s_{1}(1-(t+z))+(z-y) \sum_{i=1}^{n} s_{i}\right)
$$

The first term of this equation is larger than zero as long as $t+z<1$. The second term is always smaller than zero; it is smaller the larger $y$ relative to $z$ and the larger the size of the market(s) that can be served from the export platform in country 1. Thus, in the top panel of Figure $3 f^{X_{P} \Leftrightarrow I, 1+X_{C}}$ is increasing in $t$ albeit at a decreasing rate, while in the bottom panel the difference between $z$ and $y$ is so large that the second term in (8) outweighs the first term even for low values of $t$. This is different from the analysis in Neary (2002), his equation (10) is unambiguously negative, i.e. export-platform FDI from outside the region becomes more attractive as intra-union tariffs decrease. Here, in turn, intra-union export 
Figure 3. Supply strategies in the monopoly case with two core countries

Periphery-core distance cost small relative to within-core distance cost $(y=0.2)$

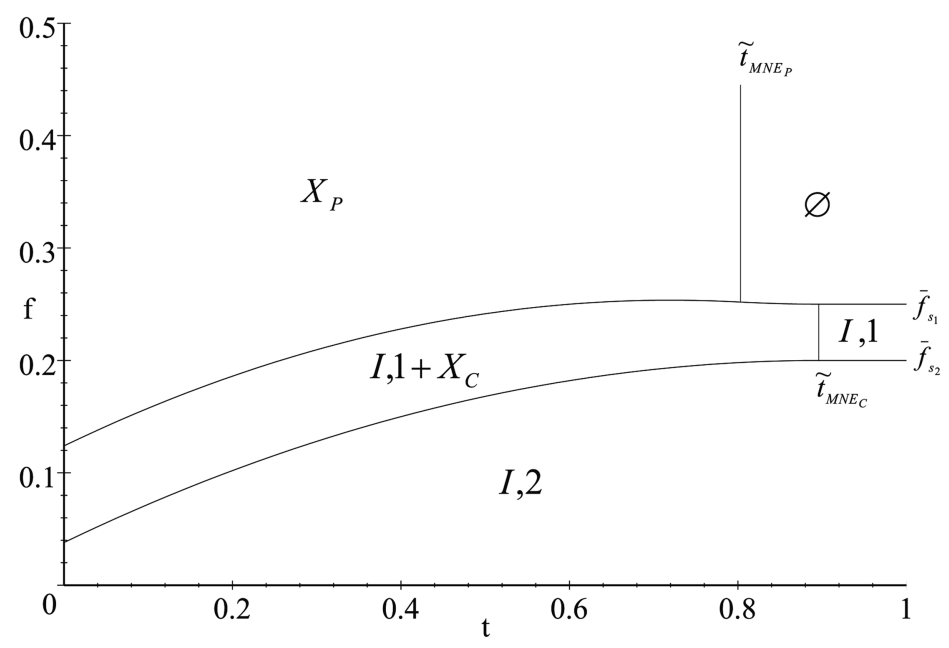

Periphery-core distance cost large relative to within-core distance cost $(y=0.7)$

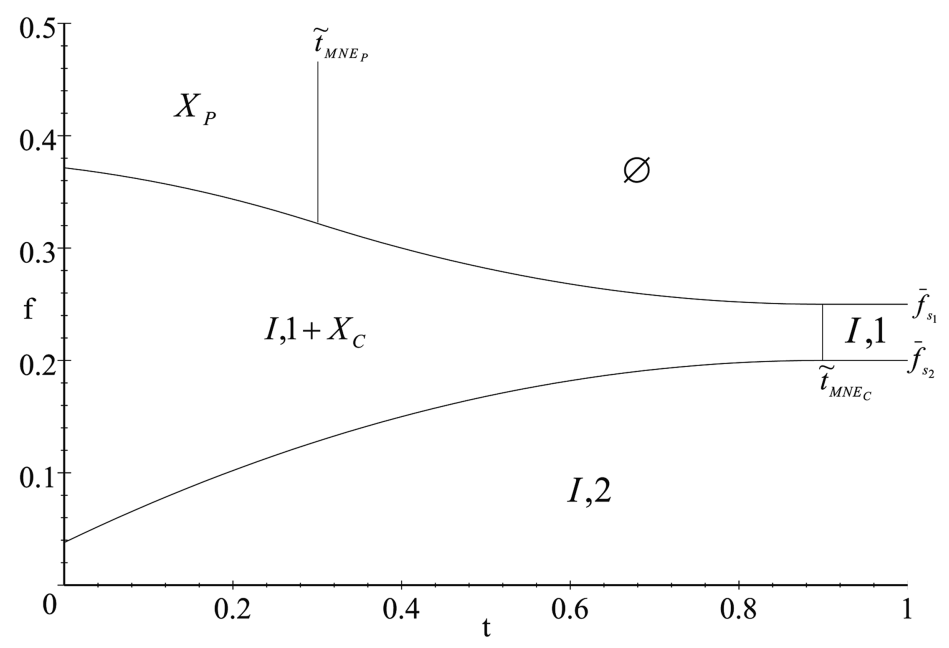

$X_{P / \mathrm{C}} \quad$ : Exports from the periphery $(\mathrm{P})$ or the core $(\mathrm{C})$

$I, n \quad:$ Investment in $n$ countries

Ø : No supply

$\tilde{t}_{M N E_{P / C}}$ : Prohibitive tariff for the MNE for exports from the periphery $(P) /$ within the core $(C)$

$\dot{f}_{s i} \quad$ : Maximum level of fixed cost covered by market size $s$ of country $i$

Parameters: $s_{1}=1, s_{2}=0.8, z=0.1$ 
platform FDI becomes more attractive than exporting to or not supplying a group of core countries when the MNE is in a rather remote location relative to these countries.

Figure 4. Supply strategies in the monopoly case with three core countries Periphery-core distance cost small relative to within-core distance cost $(y=0.2)$

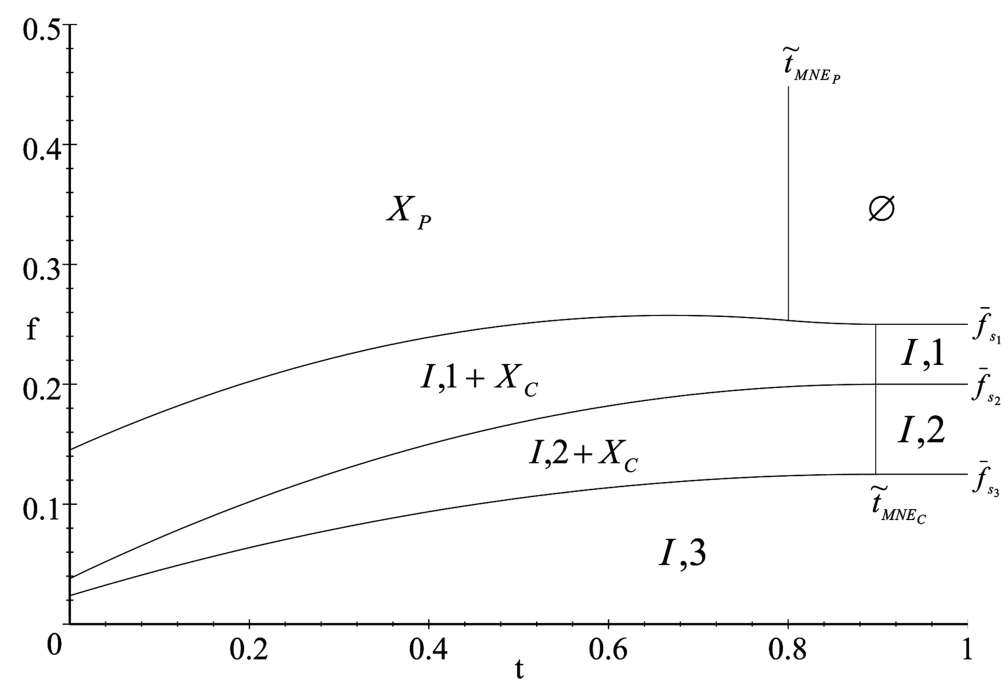

Periphery-core distance cost large relative to within-core distance cost $(y=0.7)$

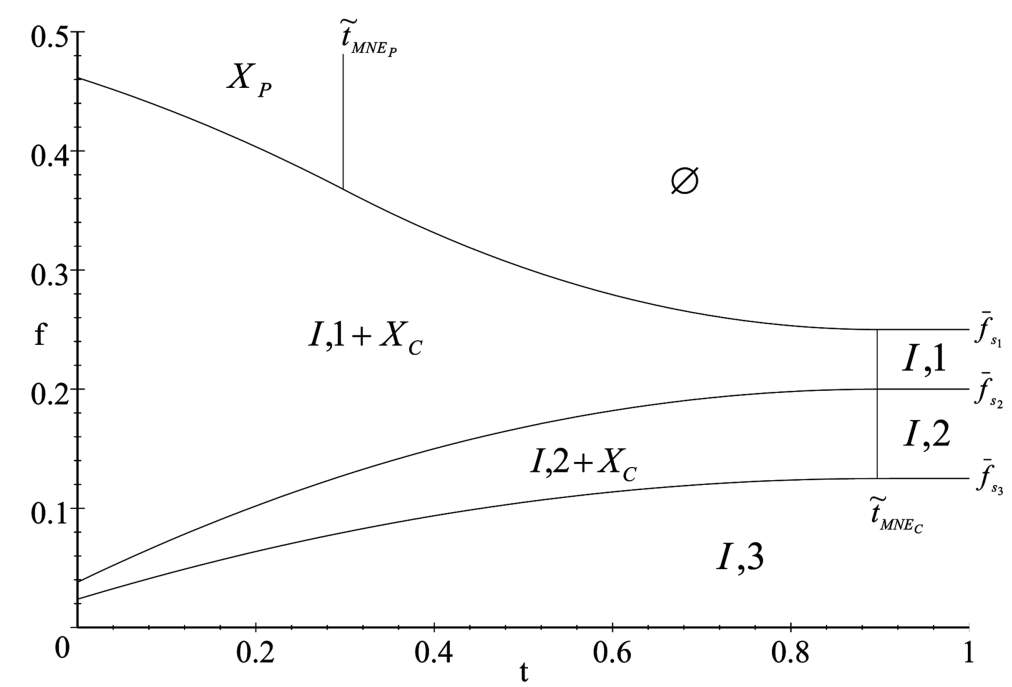

$X_{P / C} \quad:$ Exports from the periphery $(\mathrm{P})$ or the core (C)

$I, n \quad:$ Investment in $n$ countries

$\varnothing \quad$ : No supply

$\tilde{t}_{M N E_{P / C}}$ : Prohibitive tariff for the MNE for exports from the periphery (P)/ within the core (C)

$\dot{f}_{s i} \quad$ : Maximum level of fixed cost covered by market size $s$ of country $i$

Parameters: $s_{1}=1, s_{2}=0.8, s_{3}=0.5, z=0.1$ 
Figure 4 repeats the analysis for three core countries where the third core country is assumed to have market size $s_{3}=0.5$. As there are now more markets that can be served from country 1 , the region where we observe export platform investment in the largest core country $\left(I, 1+X_{C}\right)$ is larger than before. The region where there was investment in two core countries in Figure 3, in turn, is split into a region with export platform investment in the two larger core countries plus exports to the smallest core country from there $\left(I, 2+X_{C}\right)$ and a region with investment in all three core countries $(I, 3)$. The reasoning for lower fixed cost or a lower tariff barrier is qualitatively the same as in the two core country case above.

\section{The Supply Decision when the MNE Faces Competition}

The analysis conducted for the multinational as a monopolist can be regarded as a good approximation in the most innovative industries; however, it is likely that the MNE will face some sort of competition. The amount of competition introduced here is restricted to local incumbent firms in the core countries. These firms always supply their home market, and if profitable they export to the other core countries. To keep things tractable they do not have the possibility to invest abroad. All firms still treat markets as segmented. There is no entry of firms other than those mentioned so far. That is, in each market there are between two (if the tariff is such that it is profitable for the MNE to invest, but too high for the other core firms to export), and $n+1$ firms operating. ${ }^{10}$ Demands are linear with intercept and slope normalised to 1 , and firms compete in quantities. This results in a Cournot-Nash equilibrium.

Denote by $\bar{x}_{i}=\Sigma_{k=1}^{n+1} x_{k, i}$ the total amount of sales of all $k$ firms in market $i$. With total sales divided by market size $s_{i}$, the profits of firm $k$ in any market $i$ are

$$
\pi_{k, i}=\left(1-\tau_{k}^{d}-\frac{\bar{x}_{i}}{s_{i}}\right) x_{k, i}=\left(1-t_{k}-d_{k}-\frac{\bar{x}_{i}}{s_{i}}\right) x_{k, i}
$$

where trade cost $\tau_{k}^{d}$ are again composed of the tariff $t_{k}$ and the distance cost $d_{k}$. The tariff is $t_{k}=t$ for all firms that export to this market, and $t_{k}=0$ for the domestic firm and for the MNE if it decides to invest in country $i$. The distance cost $d_{k}$ is equal to $y$ for the multinational if it decides to export to a core country from its home country, it is equal to $z$ for the exports of any firm located in the core and

\footnotetext{
${ }^{10}$ Considering only cases where it is profitable for the MNE to serve the core at all.
} 
equal to zero for any firm with a plant in this market. The MNE is labelled $k=0$, the local firm in market $i$ is $k=i$, and $0<k \neq i$ is left for the incumbents in the other core countries. When profits of the multinational are referred to, the firm subscript $k$ will be suppressed in the following. From (9) the first order condition for output of firm $k$ in market $i$ is given by

$$
x_{k, i}=s_{i}\left(1-\tau_{k}^{d}-\frac{\bar{x}_{i}}{s_{i}}\right)
$$

i.e. equilibrium profits are $\pi_{k, i}=s_{i}\left(1-\tau_{k}^{d}-\frac{\bar{x}_{i}}{s_{i}}\right)^{2}$. When it is profitable for all firms to be active in market $i$, total sales in this market can be obtained as $\bar{x}_{i}=s_{i} \frac{1+n-\bar{\tau}^{d}}{n+2}$, where $\bar{\tau}^{d}=\Sigma \tau_{k}^{d}$. Plugging this back into (10), output of each firm is

$$
x_{k, i}=s_{i} \frac{1-(n+1) \tau_{k}^{d}+\bar{\tau}_{-k}^{d}}{n+2}
$$

where $\bar{\tau}_{-k}^{d}$ denotes the trade cost (i.e. the sum of the tariff and the distance cost) of all firms other than firm $k$ operating in this market. The output of the MNE, the domestic firm and a core country firm are calculated explicitly in Table 1 for the case of $n+1$ firms (lower half).

From equation (11) one can see that a firm's sales and hence its profits in a market are decreasing in its own access cost (trade cost) and increasing in its competitors' access costs to this market ${ }^{11}$ :

$$
\pi_{k, i}=\pi\left(s_{i}, \tau_{k}^{d}, \bar{\tau}_{-k}^{d}\right)
$$

By assumption, profits are increasing in market size. If trade costs change simultaneously for firm $k$ and its $n-1$ competitors, one obtains

$$
d \bar{\tau}_{-k}^{d}=(n-1) d \tau_{k}^{d} \Rightarrow \frac{d x_{k, i}}{d \tau_{k}^{d}}=\frac{\partial x_{k, i}}{\partial \tau_{k}^{d}}+(n-1) \frac{\partial x_{k, i}}{\partial \bar{\tau}_{-k}^{d}}<0
$$

\footnotetext{
${ }^{11}$ Neary (2002) proves that this result also applies to different specifications of demand functions. In his Appendix he shows that the properties in (12) hold for Bertrand as well as for Cournot competition with linear demands and differentiated products. They also hold under Cournot competition with general demands except when demands are highly convex and the firm in question has a relatively small market share.
} 
From equation (11) one can see that the direct effect dominates. Thus, as either component of the trade cost increases, output, and therefore profits, fall.

Turning to the different supply strategies, the analysis proceeds very much like in the monopoly case. Consider first the multinational's profits from exporting to all core countries

$$
\Pi^{X_{P}}=\sum_{i=1}^{n} \pi_{i}\left[s_{i}, \tau_{y} ;(n-1) \tau_{z}\right]=\sum_{i=1}^{n} \pi_{i}\left[s_{i}, t+y ;(n-1)(t+z)\right]
$$

The properties of the profit function (equation (12)) continue to hold; total profits are increasing in market size $s_{i}$, decreasing in own trade cost $t+y$ and increasing in the competitors' trade cost $t+z$. As the negative effect of own trade cost dominates (see eq. (13)) total exports are decreasing in $t$. The prohibitive tariffs differ according to the location of firms. For the multinational the prohibitive tariff for exports from its home country to market $i$ given distance cost is

$$
\tilde{t}_{M N E_{P}}=\frac{1-(n+1) \bar{y}+(n-1) \bar{z}}{2}
$$

If the MNE exports from the periphery the prohibitive tariff for exports of a core country firm to market $i$ given distance cost is

$$
\dot{t}_{C F_{X}}=\frac{1-3 \bar{z}+\bar{y}}{2}
$$

As $z$ approaches $y$ the prohibitive tariff for the MNE approaches that of a core firm. Otherwise, the prohibitive tariff for the core firms is always higher than that of the multinational: $\tilde{t}_{C F_{x}}-\tilde{t}_{M N E}=\frac{(n+2)(y-z)}{2}>0$ for $0 \leq z<y$. This implies that there are parameter values such that the MNE will never export to the core market, but where the firms in the core countries will still trade among each other. Nonnegativity constraints on (15) and (16) as well as the condition $0 \leq z<y$ reduce MNE activity and interaction with local incumbents to a smaller parameter space than in the monopoly case. If both the tariff and the within-core distance cost were zero, the MNE would find it profitable to export to the core up to a maximum value of the periphery-core distance cost of $y \leq \frac{1}{n+1}$.

If the MNE decides to invest in one core country instead, the prohibitive tariff given within-core distance cost $z$ for the core firms to this country lowers to $\tilde{t}_{C F_{I}}=\frac{1-3_{z}}{3}$. Thus, for values of trade cost larger than this, investment by the 
multinational generates duopoly profits for the MNE and the local firm in this country, with the other core firms abandoning this market. By investing in the core the MNE benefits from lower distance costs for exports to the other core markets. Its total profits from investing in, as before, the core country with the largest market size (country 1) are

$$
\Pi^{I, 1+X_{C}}=\pi_{1}\left[s_{1} ;(n-1)(t+z)\right]-f+\sum_{i=2}^{n} \pi_{i}\left[s_{i}, t+z ;(n-1)(t+z)\right]
$$

While in the monopoly case lower trade cost unambiguously increase the profits from investing, this need not always be the case under competition. Deriving (17) with respect to within-core trade cost $\tau^{z}$ gives

$$
\frac{d \Pi^{I, 1+X_{C}}}{d \tau^{z}}=\sum_{i=2}^{n} \underset{-}{2 \frac{\partial \pi_{i}^{o}}{\partial \tau^{z}}+(n-1)}\left[\begin{array}{c}
\left.\frac{\partial \pi_{1}^{c}}{\partial \tau^{z}}+\sum_{i=2}^{n} \frac{\partial \pi_{i}^{c}}{\partial \tau^{z}}\right] \\
+
\end{array}\right]
$$

where the superscripts $o$ and $c$ denote the own and the competition effect, respectively. With lower tariffs the own effect from investing in one country still increases profits. However, this means that the MNE's competitors also have easier access to market 1, and therefore the negative impact on profits due to increased competition may easily outweigh the positive own effect. In the case of the demand function employed in (9), equation (18) becomes

$$
\frac{d \Pi^{I, 1+X_{C}}}{d t}=-\frac{2}{(n+2)^{2}}\left\{2 \sum_{i=2}^{n} s_{i}-s_{1}(n-1)-(t+z)\left[s_{1}(n-1)^{2}+4 \sum_{i=2}^{n} s_{i}\right]\right\}
$$

Normalising $s_{1}$ to 1 , this says that for values of $t+z \geq \frac{1-n+2 \sum_{i=2^{s_{i}}}^{n}}{(n-1)^{2}+4 \sum_{i=2^{s_{i}}}^{n}}$ the impact from competition dominates. If all core country markets were of equal size $\left(s_{1}=s_{i}\right.$ $=1$ ), this would be equal to $t+z \geq \frac{1}{n+3} \cdot{ }^{12}$ This threshold is decreasing in the number of countries that are to be served from country 1 . If, in addition, these countries have small market sizes, the threshold for the own effect to dominate is further reduced. Taken together this implies that under competition, a lowering of trade cost is unlikely to induce a switch to export platform investment.

Comparing profits from investing in one core country with the profits from

${ }^{12}$ A similar result is obtained by Neary (2002), p. 305. 
exporting to all core countries from the periphery, yields a decomposition similar to the monopoly case:

$$
\begin{aligned}
& \Pi^{I, 1+X_{C}}-\Pi^{X_{P}}=\gamma_{y}^{C}\left(s_{1}, t+z, \quad t+y, \quad f\right) \\
& +\chi^{C}\left(s_{1}, t+z, t+y,(n-1)\right),
\end{aligned}
$$

where $\gamma_{y}^{C}\left(s_{1}, t+z, t+y, f\right)$

$$
=\pi_{1}\left[s_{1} ;(n-1)(t+z)\right]-f-\pi_{1}\left[s_{1}, t+y ;(n-1)(t+z)\right]
$$

and

$$
\begin{aligned}
& \chi^{C}\left((n-1), s_{i}, t+z, t+y\right) \\
& =\sum_{i=2}^{n}\left\{\pi_{i}\left[s_{i}, t+z ;(n-1)(t+z)\right] \dot{-} \pi_{i}\left[s_{i}, t+y ;(n-1)(t+z)\right]\right\} .
\end{aligned}
$$

The main difference to the monopoly case is that $\gamma_{y}^{C}($.) now also depends on the within-core trade and distance cost $t+z$. While this strengthens the case for setting up a plant in order to avoid the trade and distance cost, the export platform term $\chi^{C}$ (.) will rarely do anything to offset a negative $\gamma_{y}^{C}$ (.) as the negative competition effect (eq. (18)) is likely to dominate in the presence of core country firms. The profits from investing in $m$ core countries in the order of their market size can be written as

$$
\begin{gathered}
\Pi^{I, m}=\sum_{i=1}^{m}\left\{\pi_{i}\left[s_{i} ;(n-1)(t+z)\right]-f\right\}+\sum_{i=m+1}^{n} \pi_{i}\left[s_{i}, t+z ;(n-1)(t+z)\right] \\
=\Pi^{I, m-1}+\gamma_{z}^{C} \quad\left(s_{m}, t+z, f\right) . \\
+\quad+\quad-
\end{gathered}
$$

Also here, as long as $\gamma_{z}^{C}$ (.) is positive, it is profitable to establish plants in further core countries.

In the range of parameters where investment by the MNE gives rise to a duopoly by deterring exports from the core country incumbents, the trade cost avoiding gain in equation (20) becomes $\gamma_{y}^{D}\left(s_{1}, t+y, t+z, f\right)=\pi_{1}^{D}\left(s_{1}\right)-f-$ $\pi_{1}\left[s_{1}, t+y ;(n-1)(t+z)\right]$. This expression now depends negatively on the within-core trade cost $t+z$. However, from (13) note that the direct effect of the peripherycore distance cost $y$ in $\pi_{1}\left[s_{1}, t+y ;(n-1)(t+z)\right]$ dominates. 
Figure 5. Supply strategies in the competition case for $y=0.2$

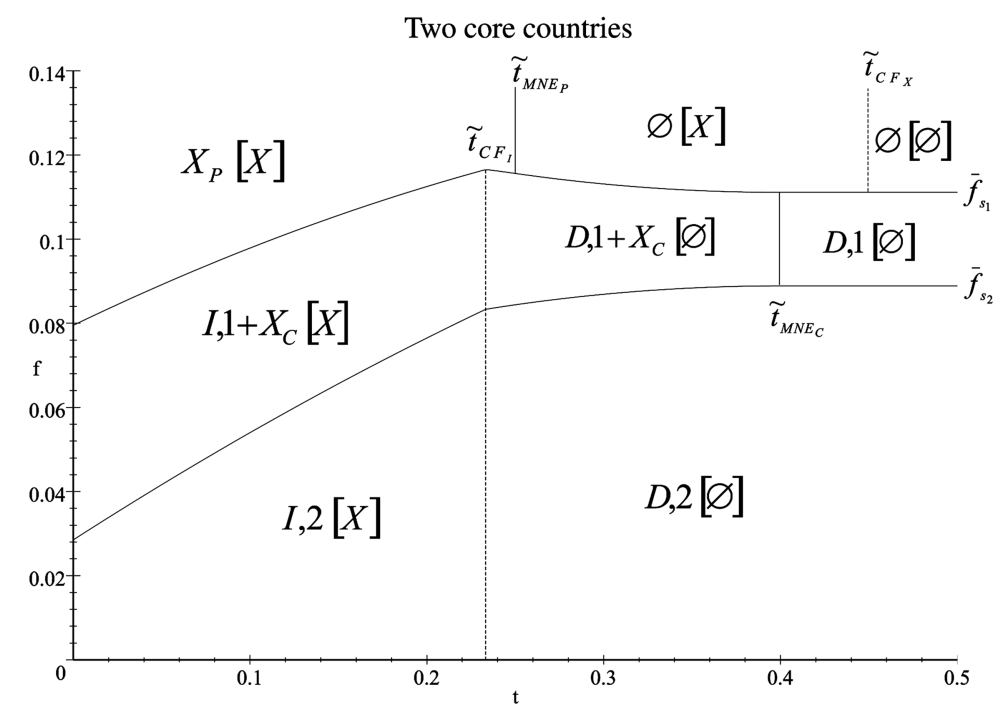

Three core countries

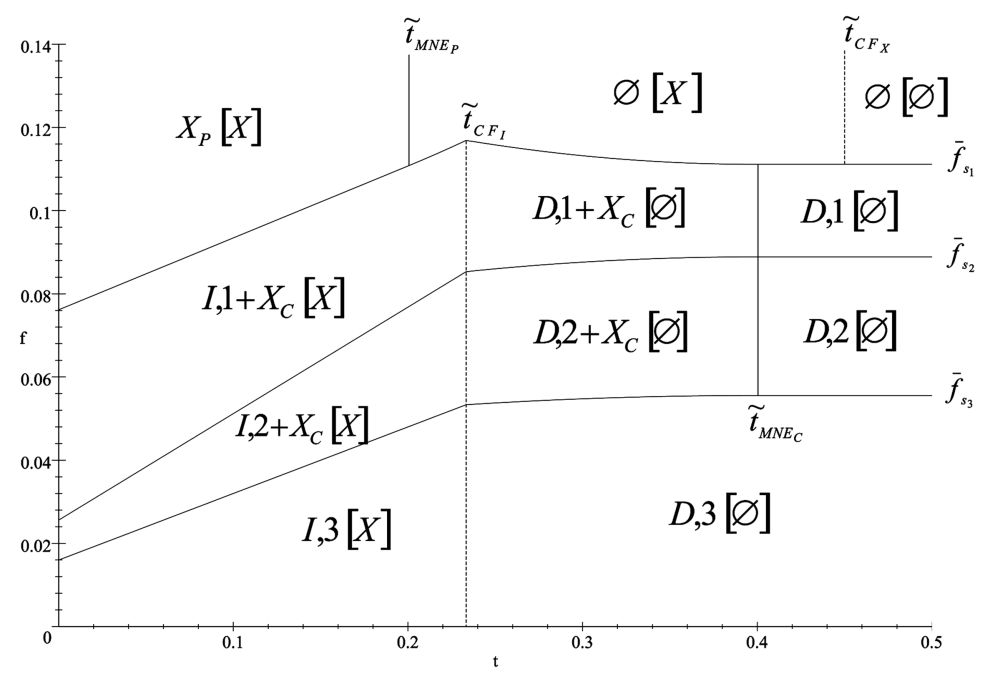

$X_{P / C} \quad$ : Exports by the MNE from the periphery (P) or the core (C)

$I, n / D, n:$ Investment/duopoly outcome in $\mathrm{n}$ countries

$\varnothing \quad$ : No supply

$\tilde{t}_{M N E_{P / C}}$ : Prohibitive tariff for the MNE for exports from the periphery (P)/ within the core (C)

$\tilde{t}_{C F_{X / I}} \quad$ : Prohibitive tariff for the core firms if the MNE exports from the periphery (X) or invests (I)

$\tilde{f}_{s_{i}} \quad$ : Maximum level of fixed cost covered by market size $s$ of country $i$

[supply mode of core country firms]: $[X]$ - exports, $[\varnothing]$ - no supply

Parameters: $s_{1}=1, s_{2}=0.8, s_{3}=0.5, z=0.1, y=0.2$ 
Overall the picture remains similar to that of the monopoly case in the presence of competition. On the one hand, it is less attractive for the MNE to engage in the core at all as lower trade and investment barriers favour competition between the MNE and the core firms. On the other hand, if fixed costs are such that investing in at least one core country is profitable and within-core distance cost are not too low, investment by the MNE can even deter competition from the other core country firms. Thus, this case can be held representative for some of the greenfield investment. It is also indicative of the increase in exports at the time of the SMP, in particular the increase in intra-industry trade in industries with high non-tariff barriers (EC, 1998b, p. 115).

\section{Example with linear demands and Cournot competition}

Output for the different firms under alternative supply strategies of the MNE (when all firms are active) is calculated in the lower part of Table 1. The threshold between investing in core country 1 and exporting from the periphery (cf. equation (20)) can be calculated as

$$
\begin{aligned}
f^{X_{P} \Leftrightarrow I, 1+X_{C}}=s_{1}\left(\frac{1+(n-1)(t+z)}{n+2}\right)^{2} \\
+\sum_{i=2}^{n} s_{i}\left(\frac{1-2(t+z)}{n+2}\right)^{2}-\Sigma_{i=1}^{n} s_{i}\left(\frac{1-2 t-(n+1) y(n-1) z}{n+2}\right)^{2}
\end{aligned}
$$

This holds for tariffs up to the prohibitive level for the MNE $\tilde{t}_{M N E_{P}}=\frac{1-(n+1) y+(n-1) z}{2}$. Above that export platform investment in core country 1 by the MNE has to be compared to not supplying the core. Note that here, the higher the periphery-core distance cost $y$, the less likely it is that the MNE exports from the periphery at all. Core country firms, on the other hand, will only stop exporting within the core for $\tilde{t}_{C F_{X}}>\frac{1-3 z+y}{2}$. If, however, fixed costs are such that the MNE invests, then core firms will already stop exporting above $\tilde{t}_{C F_{I}}=\frac{1-3 z}{3}$. For trade barriers higher than this, the MNE shares the market in country 1 only with the local incumbent. In this case, the first-term in equation (22) has to be replaced by the Cournot duopoly profits of $s_{1}\left(\frac{1}{3}\right)^{2}$; the other terms remain unchanged.

For investment in additional countries the threshold between investing in $m$ and $m-1$ core countries (equation (21)) is given by 


$$
f^{I, m \Leftrightarrow I, m-1}=s_{m}\left(\frac{1+(n-1)(t+z)}{n+2}\right)^{2}-s_{m}\left(\frac{1-2(t+z)}{n+2}\right)^{2}
$$

In this equation too, for tariffs above $\tilde{t}_{C F_{I}}$, the first term has to be replaced by the Cournot duopoly profits of $s_{m}\left(\frac{1}{3}\right)^{2}$.

Thus, as can be seen from Figure 5, strategic interaction increases the number of possible out-comes of the MNE's supply decision. The two graphs depict the same situation as in the upper panels of Figures 3 and 4 for the case with competition ( 2 and 3 countries, $\left.s_{1}=1, s_{2}=0.8, s_{3}=0.5, z=0.1, y=0.2\right)$. In square brackets are the supply strategies for the core country firms (exports $[X]$ or no supply $[\varnothing]$ ).

Looking at fixed cost first, if the tariff is held fixed at a level below the prohibitive level for exports $\left(\tilde{t}_{M N E_{P}}\right)$, the MNE will export from the periphery $\left(X_{P}\right)$. For lower values of fixed cost there will be export platform investment $\left(I, i+X_{C}\right)$ or investment in all core countries $(I, 2$ or $I, 3)$ as before. When the trade barrier is above the prohibitive level for exports by the MNE and fixed costs are high, the MNE will not supply the core at all, while core country firms may still find it profitable to export within the core $(\varnothing[X])$. For lower values of fixed cost, investment in one core country by the MNE may make it unprofitable for the core firms to export to this market. In this case, the MNE and the local incumbent earn duopoly profits in this country. Such investment serves as an export platform $\left(D, i+X_{C}\right)$ up to the prohibitive tariff for exports by the MNE within the core $\tilde{t}_{M N E_{C}}$, above which the MNE keeps its plant, but stops exporting $(D, i)$.

Starting at intermediate levels of fixed cost and a high tariff, a decrease in tariff barriers first allows the MNE to export from the country where it has established a plant to the other core countries $\left(D, i\right.$ to $\left.D, i+X_{C}\right)$ without competition from other core country firms. When tariff barriers decrease below $\tilde{t}_{C F_{I}}$, the MNE's profits from investing are diluted as core firms find it profitable to export as well.

Instead, assuming the initial level of fixed cost and the tariff to be in the no supply area (ø $[\varnothing])$, lower tariff barriers will induce the MNE to export from the periphery $\left(\varnothing\right.$ to $X_{P}$ ). The case where a lower tariff induces export platform investment as in the monopoly case is unlikely to arise here. The derivative of (22) with respect to $t$ illustrates this:

$$
\left.\frac{\partial f^{X_{p} \Leftrightarrow I, 1+X_{C}}}{\partial t}=2 \frac{(n+1)}{(n+2)^{2}}[1+(n-1) z+(n-3) t-2 y) s_{1}+2(z-y) \sum_{i=2}^{n} s_{i}\right]
$$


Like in the monopoly case the last term inside the square bracket is always smaller than zero, the more so the larger $y$ relative to $z$ and the larger the markets that can be served from core country 1 . In contrast to the monopoly case though, the term pertaining to $s_{1}$ here includes a negative argument for $y$, which is likely to render this part small or even negative (especially if the core consists of only a few core countries).

For this reason and to preserve space the graphs for $y=0.7$ corresponding to the lower panels of Figures 3 and 4 are not displayed here. The difference to the $y=0.2$ case in Figure 5 is that the region where the MNE exports from the periphery disappears from the picture. In turn, export platform investment in country 1 will be profitable up to slightly higher values of $f$, the slope of this threshold remains smaller than 1 though.

Summarising, due to competition, trade and investment barriers need to fall by more than in the monopoly case for the MNE to engage in the core. If it is profitable for the MNE to invest, however, it may be able to deter competition from exporters with its investment.

\section{Concluding Remarks}

This paper analyses the decision of a multinational enterprise located inside an integrating region whether to supply a group of other countries in this region by investing there or via exports. Investing involves a fixed cost to establish production facilities. Exports, in turn, are subject to a trade cost of which one part is due to remaining trade barriers ('tariff') and the other part depends on the distance of the multinational's production facilities to its destination markets. The destination countries ('core') are assumed to be close to each other, either geographically or in terms of cultural linkages.

The model provides a rationale for the reactions of multinational enterprises to the policies taken during the Single Market Programme that are consistent with the aggregate dynamics in foreign direct investment and trade during this period within the European Union. Starting from different levels, both a lowering of (non-tariff) barriers to trade and a decrease in barriers to investment may induce export platform investment also within an integrating region when the assumption of countries inside the region being perfectly homogenous is dropped. In addition to an overall friendlier environment to-wards foreign direct investment, this may well have been among the main drivers of the near doubling of intra-EU direct 
investment.

MNE activity in the model is motivated by market-seeking motives throughout. It does not account for other considerations such as, for example, factor cost considerations which may well have been at the root of the increase in FDI flows going from the core (the founding members of the EU plus the UK) to the periphery between 1980 and 1992 (see Morsink, 1998, p. 69). Next to this, future research should develop the analysis further by allowing for competition from other potential multinationals and for reciprocal investment in an intra-union setting. Ekholm, Forslid and Markusen (2007) explore these directions in a setting where the multinational is located outside the customs union.

\section{Acknowledgements}

I am grateful for valuable discussions with Fernando Domínguez Iñiguez, Liliane Karlinger, Jörn Kleinert, Stefan Kohler, Massimo Motta, Karl Schlag and Jochen Schanz. Any remaining errors are my own.

Received 10 September 2007, Revised 25 February 2010, Accepted 3 March 2010

\section{References}

Balassa, B.A. (1975), "Trade Creation and Trade Diversion in the European Common Market. An Appraisal of the Evidence", Manchester School of Economic and Social Studies, Vol. 42, pp. 93-135.

Bende-Nabende, A. (2000), "Foreign Direct Investment in ASEAN: An Historical Perspective". In R. Strange, J. Slater and C. Molteni (eds.) The European Union and ASEAN: Trade and Investment Issues, (Basingstoke, Hampshire et al.: Macmillan).

Clegg, J. (1998), "The Determinants of Intra-European Foreign Direct Investment Flows:

Market Inte-gration and Policy Issues", Journal of Transnational Management Development, Vol. 3(3/4), pp. 89-129.

Dunning, J.H. (1997a), “The European Internal Market Programme and Inbound Foreign Direct In-vestment: Part 1”, Journal of Common Market Studies, Vol. 35(1), pp. 1-30. Dunning, J.H. (1997b), "The European Internal Market Programme and Inbound Foreign Direct In-vestment: Part 2", Journal of Common Market Studies, Vol. 35(2), pp. 189223.

Ekholm, K.; Forslid, R. and J.R. Markusen (2007), "Export-Platform Foreign Direct Investment”, Jour-nal of the European Economic Association, Vol. 5(4), pp. 776-95. E[uropean] C[ommission] (1997), The 1996 Single Market Review: Background 
information for the Report to the Council and European Parliament (Luxembourg). EC (1998a), The Single Market Review, Subseries IV: Impact on Trade and Investment, Volume 1: Foreign Direct Investment (Luxembourg).

EC (1998b), The Single Market Review, Subseries IV: Impact on Trade and Investment, Volume 2: Trade Patterns inside the Single Market (Luxembourg).

EC (1998c), The Single Market Review, Results of the Business Survey (Luxembourg). European Economy (1999), Supplement A, Mergers and Acquisitions, No. 2.

Fontagné, L. and Pajot, M. (2001), "Foreign Trade and FDI Stocks in British, US and French Industries: Complements or Substitutes?", In N. Pain (ed.) Inward Investment, Technological Change and Growth: The Impact of Multinational Corporations on the UK Economy (Houndsmills and New York: Palgrave), pp. 240-263.

Head, K. and Mayer, T. (2000), "Non-Europe: The Magnitude and Causes of Market Fragmentation in the EU", Weltwirtschaftliches Archiv, Vol. 136(2), pp. 284-314.

Markusen, J.R. (2002), Multinational Firms and the Theory of International Trade (Cambridge, Mass. and London: MIT Press).

Monti, M. (1996), The Single Market and Tomorrow's Europe: A Progress Report from the European Commission (European Communities: Luxembourg).

Morsink, R.L.A. (1998), Foreign Direct Investment and Corporate Networking: A Framework for Spatial Analysis of Investment Conditions (Cheltenham and Northampton, Mass.: Edward Elgar).

Motta, M. and Norman, G. (1996), "Does Economic Integration Cause Foreign Direct Investment?", International Economic Review, Vol. 37(4), pp. 757-783.

Neary, J.P. (2002), "Foreign Direct Investment and the Single Market", The Manchester School, Vol. 70(3), pp. 291-314.

Nitsch, V. (2000), "National Borders and International Trade: Evidence form the European Union", Canadian Journal of Economics, Vol. 33(4), pp. 1091-1105.

Norman, G. and Motta, M. (1993), "Eastern European Economic Integration and Foreign Direct Investment", Journal of Economics \& Management Strategy, Vol. 2(4), pp. 483-507.

OECD (1993, 1996), International Direct Investment Yearbook 1993, 1996 (Paris: OECD).

OECD (2002), www.sourceoecd.org International Direct Investment; Main Economic Indicators; Monthly International Trade.

Pain, N. (1997), "Continental Drift: European Integration and the Location of U.K. Foreign Direct Investment", The Manchester School Supplement, pp. 94-117.

Pain, N. and Lansbury, M. (1997), "Regional Economic Integration and Foreign Direct Investment: The Case of German Investment in Europe", National Institute Economic Review, Vol. 160(2), pp. 87-99.

Rowthorn, R.E. (1992), "Intra-industry Trade and Investment under Oligopoly: The Role of Market Size", Economic Journal, Vol. 102(411), pp. 402-414.

Rugman, A.M. (1994) (ed.), Foreign Investment and NAFTA (Columbia, S.C.: University of South Carolina Press).

Sleuwaegen, L. (1998), "Foreign Direct Investment, Cross-Border Mergers and 
Competition Policy in the European Union”, In K. Kukasaku, F. Kimura and S. Urata (eds.) Asia and Europe: Beyond Competing Regionalism (Brighton and Portland, Oreg.: Sussex Academic Press).

van Aarle, B. (1996), "The Impact of the Single Market Programme on Trade and Foreign Direct Investment in the European Union", Journal of World Trade, Vol. 30(6), pp. 123-138.

Yannopoulos, G.N. (1990), "Foreign Direct Investment and European Integration: The Evidence from the Formative Years of the European Community", Journal of Common Market Studies, Vol. 28(3), pp. 235-259. 